\title{
A cornealis sebgyógyulás és az extracelluláris mátrix
}

\author{
Varkoly Gréta dr. ${ }^{1}$ - Bencze János ${ }^{1}$ \\ Hortobágyi Tibor $\mathrm{dr}^{\mathrm{1}^{*}}$ - Módis László $\mathrm{dr} .^{2^{*}}$
}

${ }^{1}$ Debreceni Egyetem, Általános Orvostudományi Kar, Patológiai Intézet, Neuropatológiai Tanszék, Debrecen

${ }^{2}$ Debreceni Egyetem, Klinikai Központ, Szemklinika, Debrecen

\begin{abstract}
A bulbusra óraüvegszerúen ráfekvő cornea a szem első fénytörő közege. A szaruhártya átlátszóságát az azt felépítő rendezett, lamellaris elhelyezkedésű kollagénrostoknak, valamint a rostok között kapcsolatot teremtő, leucinban gazdag proteoglikánoknak köszönheti. A felnőttcorneát főként fibrilláris kollagénrostok építik fel. A fibrillumokhoz kapcsolódó kollagének és a nonfibrilláris kollagének kisebb mennyiségben vannak jelen a szaruhártyában. A cornea fó proteoglikánjai keratán-szulfát-tartalmú proteoglikánok, amelyek mellett dermatán-szulfát-tartalmú proteoglikánok is megtalálhatók. A proteoglikánszintézis defektusai az egyedi szerkezet felbomlásához, a normálisnál vastagabb átmérőjü kollagénrostok kialakulásához vezet. Az abnormális extracellulárismátrix-szerkezet cornealis betegségeket, ezáltal a szaruhártya transzparenciájának elvesztését eredményezi. A proteoglikánok és kollagénrostok a sebgyógyulásban is kiemelt szerepet töltenek be. A corneát ért sérülés következtében az extracelluláris mátrixot termelő keratocyták növekedési faktorok hatására fokozott kollagén- és proteoglikánszintézisbe kezdenek. A különböző növekedési faktorok a sérült corneában több helyről származhatnak. A sebgyógyulásban részt vevő sejtek és növekedési faktorok arányától függően rendezett extracelluláris mátrix vagy hegszövet alakul ki. Orv. Hetil., 2016, 157(25), 995-999.
\end{abstract}

Kulcsszavak: cornealis kollagének, cornealis proteoglikánok, cornealis extracelluláris mátrix, cornealis sebgyógyulás

\section{The corneal wound healing and the extracellular matrix}

The cornea is the first refractive element of the eye. The transparency of the cornea results from the regularly arranged collagen fibrils, forming lamellar structure and the leucin rich proteoglycans, which make interactions between the fibrils. The adult cornea consists mainly of fibril-forming collagens. The cornea has less amount of fibril associated and non-fibrillar collagens. The main proteoglycans of the cornea are keratan-sulfate proteoglycans and it also contains dermatan-sulfate proteoglycans. Disorders of the proteoglycan synthesis lead to the disruption of the unique pattern and result in thicker collagen fibrils. The abnormal structure of the extracellular matrix can generate corneal disorders and the loss of corneal transparency. Furthermore, proteoglycans and collagens have an important role in wound healing. In injury the keratocytes produce higher amounts of collagens and proteoglycans mediated by growth factors. Depending on the ratio of the cells and growth factors the extracellular matrix returns to normal or corneal scar tissue develops.

Keywords: corneal collagens, corneal proteoglycans, corneal extracellular matrix, corneal wound healing

Varkoly, G., Bencze, J., Hortobágyi, T., Módis, L. [The corneal wound healing and the extracellular matrix]. Orv. Hetil., 2016, 157(25), 995-999.

(Beérkezett: 2016. március 17.; elfogadva: 2016. április 21.)

\section{Rövidítések}

CTGF $=$ (connective tissue growth factor) kötőszöveti növekedési faktor; $\mathrm{ECM}=$ extracelluláris mátrix; $\mathrm{EGF}=($ epidermal growth factor) epidermalis növekedési faktor; FACIT $=($ fibrilassociated collagens with interrupted triple helices) fibrillu- mokhoz kapcsolódó kollagének; FGF-2 = (fibroblast growth factor) fibroblastnövekedési faktor; GAG = glükózaminoglikán; IGF-I = (insulin-like growth factor I) inzulinszerü növekedési faktor I; IGF-II = (insulin-like growth factor II) inzulinszerú növekedési faktor II; IL-I = interleukin-1; KGF = 
(keratinocyte growth factor) keratinocytanövekedési faktor; PG $=$ proteoglikán; TGF- $\alpha=($ transforming growth factor $\alpha)$ transzformáló növekedési faktor $\alpha$; TGF- $\beta=$ (transforming growth factor $\beta$ ) transzformáló növekedési faktor $\beta$

A cornea a szem első fénytörő közege. A szaruhártya a szem külső, rostos burkát alkotja a sclerával együtt. Mikroszkopikusan öt rétegből áll. A külső, külvilág felé eső réteg az epithelium corneae. Alatta helyezkedik el a Bowman-membrán (membrana limitans anterior). A szaruhártya középső, annak 90\%-át kitevő rétege a stroma corneae. A Descemet-membrán (membrana limitans posterior) a stroma alatt helyezkedik el. A legbelső réteg az endothelium corneae [1] (1. ábra).

A cornea stromája extracelluláris mátrixban gazdag réteg, amely fóleg kollagénrostokból és proteoglikánokból épül fel, amelyek között módosult fibroblastok, a keratocyták (a stroma volumenének 2-3\%-át teszik ki) foglalnak helyet [2]. A szaruhártya átlátszóságát a rendezett, egyenlő átmérőjű, egymástól egyenlő távolságban lévő, ortogonális lamellákba rendeződő kollagénrostoknak köszönheti. Ezen egyedi szerkezet kialakításában a proteoglikánok is fontos szerepet játszanak [1]. A stromát felépítő kollagénrostok főként fibrilláris kollagének (I-es és V-ös típusú kollagénrostok). Ezek mellett kisebb mennyiségben megtalálhatók az úgynevezett FACITkollagének (fibril-associated collagens with interrupted triple helices) (XII-es és XIV-es típusú kollagének), valamint nonfibrilláris rostok (XIII-as és XVIII-as típusú kollagénrostok) [1,3].

A stromában négy, leucinban gazdag proteoglikán van jelen: decorin, lumican, mimecan, keratocan. A decorin dermatán-szulfát-tartalmú proteoglikán. Az interfibrilláris távolság szabályozása révén a stromalis lamellák pontos elrendeződéséért felelős [4]. A lumican, mimecan és keratocan keratán-szulfát-tartalmú proteoglikánok, feladatuk a kollagénrostok átmérőjének kialakítása [5]. Kis mennyiségben heparán-szulfát-molekulák is megjelennek a stromalis extracelluláris mátrixban, amelyeket az epithelium termel [1].

\section{Stromalis kollagének}

\section{Kollagénszintézis}

Jelenleg 28 -féle kollagéntípus ismert [1]. Minden kollagénmolekula trimer, azaz három polipeptidlánc ( $\alpha$-lánc) egymás köré tekeredve tripla helixet alkot [6], így a kollagénmolekula 1, 2 vagy 3 különböző gén terméke lehet. Az $\alpha$-lánc háromféle aminosavból épül fel. A láncon belül minden harmadik aminosav glicin, amelyet rendszerint hidroxi-lizin vagy hidroxi-prolin előz meg, és általában prolin követ (2. ábra). A hidroxi-prolin kulcsszerepet tölt be a tripla helix stabilizálásában, a hidroxi-lizin pedig a glikolizációban fontos, mivel a hidroxi-lizil-maradékokhoz cukorcsoportok kapcsolódnak.

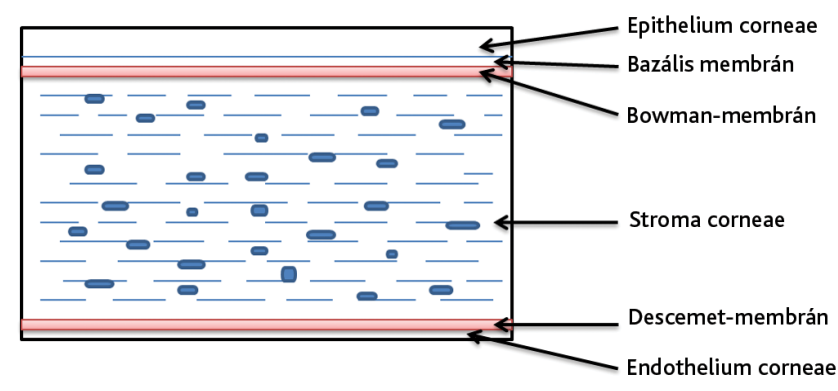

1. ábra |A cornea rétegei

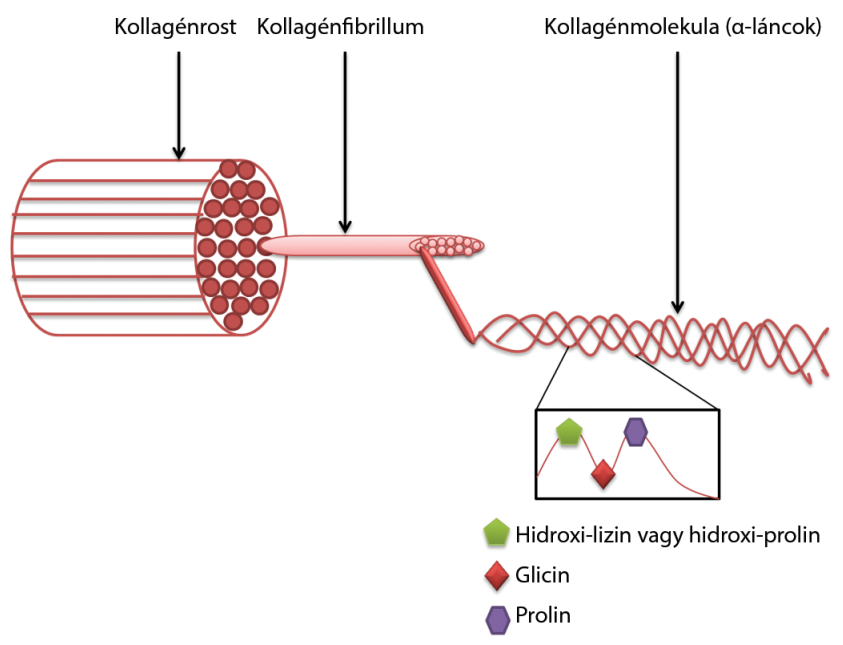

2. ábra | A kollagénrost szerkezete

A kollagénszintézis intra- és extracelluláris lépések sorozata. A kollagénmolekula szintézise a fibroblastok durva felszínú endoplazmatikus reticulumában (rough endoplasmic reticulum - rER) kezdődik. Az itt képződő polipeptid láncok bekerülnek a rER és a Golgi-készülék ciszternáiba, ahol a polipeptid lánc fontos poszttranszlációs módosulásai játszódnak le. A 20 aminosavból álló szignálpeptid lehasadásán kívül a prolin és lizin aminosavak hidroxilálása, majd egyes hidroxilmaradékok glikolizációja is megtörténik. Ezt követően három polipeptid lánc tripla helixet alkot, amelyben minden egyes $\alpha$-lánc 1014 aminosavból áll. A polipeptid láncok terminális szakaszai, az $\mathrm{N}$ - és C-terminális propeptidek nem tekerednek fel, ezek globuláris formát öltenek és diszulfidhidakat tartalmaznak. A polipeptid láncok között hidrogénkötések alakulnak ki, amelyek stabilizálják a kollagénmolekula alakját. Az így képződött molekula a prokollagén.

Miután a prokollagénmolekula exocytosissal kijut a szekretoros vesiculumokból, a kollagénszintézis lépései extracellulárisan folytatódnak. A sejtmembránhoz kötött prokollagén-peptidáz lehasítja a globuláris $\mathrm{N}$-és C-terminális doméneket, ezáltal kialakul a kollagénmolekula [7]. 


\section{Proteoglikánok a corneában}

Minden proteoglikán (PG) molekula egy tengelyfehérjéből (core proteinből) épül fel. Ehhez egy vagy több glükózaminoglikán (GAG) oldallánc kapcsolódik, amelyek ismétlődő diszacharid egységekből álló hosszú láncú poliszacharidok [8]. Ezek akár a 70 kDa-os méretet is elérhetik [4]. A proteoglikánok mindegyike besorolható a következő három csoport valamelyikébe: kapcsolódhatnak a plazmamembránhoz, hialuronsavhoz (a hialuronsav egy olyan GAG, amely nem kapcsolódik tengelyfehérjéhez) vagy a kollagénmolekulák fibrillummá formálódását modulálják [4].

A PG-molekulák GAG-oldalláncukról kapják nevüket, így a GAG-láncok alapján a PG-k három típusát különítjük el. Kondroitin/dermatán-szulfát, keratán-szulfát- és heparán-szulfát-tartalmú proteoglikánok.

A tengelyfehérjék a durva felszínú endoplazmatikus reticulumban szintetizálódnak, majd GAG-oldalláncok kapcsolódnak hozzájuk a Golgi-készülékben [9]. A dermatán-szulfát és heparán-szulfát szerin oldalláncokon keresztül kapcsolódik a PG-molekula felszínéhez, míg a keratán-szulfát aszparaginhoz kötődik. A cornealis proteoglikánok szoros kapcsolatba lépnek az extracelluláris mátrix más komponenseivel.

\section{A stromalis extracelluláris mátrix (ECM) összetétele}

A cornea stromája döntően kollagénrostokból és proteoglikánokból áll. A kollagénrostok között kis számban keratocyták [10], monocyták és dendritikus sejtek helyezkednek el.

A corneát főként fibrilláris kollagénrostok építik fel (I-es, III-as, V-ös, VI-os, XI-es típusú kollagének). A FACIT-kolllagének (XII-es és XIV-es típusú kollagének) és a nonfibrilláris kollagének (XIII-as és XVIII-as típusú kollagének) kisebb mennyiségben vannak jelen a szaruhártyában (1. táblázat).

A fó stromális fibrilláris kollagének az I-es és V-ös típusú kollagének [11], amelyeket a lamellák között elhelyezkedő keratocyták termelnek. Az I-es típusú kollagén, fó fibrilláris kollagénként a stromális rostok 80-90\%-át alkotja, míg az V-ös típusú kollagén minor fibrilláris kollagén, amely a rostok 10-20\%-át teszi ki a cornea stromájában [12]. Az V-ös típusú kollagén a leucinban gazdag proteoglikánokkal együtt fontos regulációs szerepet tölt be a kollagénrostok egyenlő átmérőjének kialakításá-

1. táblázat | Cornealis kollagének

\begin{tabular}{ll}
\hline Fibrilláris kollagének & I, III, V, VI, XI \\
\hline FACIT-kollagének & XII, XIV \\
\hline Non-fibrilláris kollagének & XIII, XVIII \\
\hline
\end{tabular}

FACIT $=$ fibril-associated collagens with interrupted triple helices. ban. Az V-ös típusú kollagének a fibrillumok szerveződése során az I-es típusú rostok közé interkalálódnak. Erre a regulációs szerepre bizonyítékul szolgál az, hogy amennyiben az V-ös típusú kollagének százalékos aránya csökken, a kollagénrostok átmérője növekszik, mennyiségük pedig csökken [13].

A fibrillumok egyedi elrendeződésében és egyenlő átmérőjének kialakításában az V-ös típusú kollagének mellett a FACIT-kollagének és GAG-okkal asszociált PGmolekulák is részt vesznek azáltal, hogy kapcsolódnak a fibrilláris kollagének felszínéhez [8]. A GAG-ok a PGmolekulák tengelyfehérjéin keresztül kapcsolódnak a kollagénhez, mégpedig úgy, hogy hat PG-molekula kapcsolódik egy kollagénmolekulához, ezáltal a fibrillumon belül minden egyes kollagénmolekulát hat szomszédos kollagén vesz körül [14].

A felnőtt, humán cornea négy proteoglikánt tartalmaz. A decorin dermatán-szulfát-tartalmú proteoglikán, szerepe a stromalamellák pontos elrendeződésének szabályozása az egyenlő interfibrilláris távolság kialakítása révén. A lumican, a keratocan és a mimecan keratánszulfát-tartalmú PG-k [15, 16], amelyek az V-ös típusú kollagénnel a kollagénrostok átmérőjének szabályozásáért felelősek [12].

Egereken végzett vizsgálatok során kimutatták, hogy a lumican gén (homozigóta) deletiója esetén a kollagénrostok átmérőjének szabályozása zavart szenvedett, így magas százalékuk abnormálisan vastag volt, amelynek következtében bilateralis cornealis homály alakult ki. Ezenfelül a lumican fontos szerepet játszik a sebgyógyulásban. Immunológiai folyamatokban a macrophagok a keratán-szulfát oldalláncok eltávolítása után a lumican tengelyfehérjéjéhez kapcsolódnak [17].

A proteoglikánszintézis defektusai a fibrillumok organizációjának megbomlásához vezetnek, ami eleinte cornealis homályt, majd akár vakságot okozhat [18]. A keratán-szulfát PG-szintézis-károsodása cornealis dystrophiához vezet, amely a szaruhártya öröklött, nem gyulladásos megbetegedése [19]. A tengelyfehérjét kódoló gén mutációja cornea planát okoz, amely a szaruhártya görbületének ellaposodását jelenti [20].

\section{Extracellulárismátrix-szintézis a cornealis sebgyógyulás során}

Embrionális korban a keratoblastok termelik a stromalis extracelluláris mátrixot, amely fóleg hialuronsavból és vízből áll [21]. A cornea ebben a fejlődési stádiumban vastagabb, és végleges transzparenciájának még csak 40\%-át érte el. Később a keratoblastok keratocytákká differenciálódnak az embrionális stromában, bár ekkor még nem szintetizálnak a felnőtt extracelluláris mátrixra jellemző, elegendő mennyiségű kollagént és keratán-szulfát-tartalmú proteoglikánt. A kollagénben és PG-kben gazdag stromalis ECM későbbi, 100\%-os transzparenciát biztosító elrendeződésének kialakulásáért a keratocyták felelősek. 
A fejlett, sérüléstől mentes szaruhártyában a stromalis keratocytákat folyamatos, de minimális kollagén- és PGszintézis jellemzi. Sebgyógyulás esetében azonban a keratocyták különböző növekedési faktorok hatására aktiválódnak, és intenzív extracellulárismátrix-szintézisbe kezdenek a stroma szerkezetének helyreállítása érdekében [4].

Ha az epitheliumon keresztül a stromát is sérülés éri, az epithelialis sejtek által termelt IL-1 a stromába diffundál és Fas-Fas ligand kapcsolatok által a sebzés szomszédságában elhelyezkedő keratocyták apoptózison mennek keresztül [22]. Az életképes keratocyták aktiválódnak és ECM-et termelnek. A sebzés kapcsán a stromában átmeneti hipercellularitás alakul ki. Ezt a hipercellularitást olyan myofibroblastok hozzák létre, amelyek citoplazmája $\alpha$-simaizom-aktint tartalmaz. Az $\alpha$-simaizom-aktin egy protein, amely a seb összehúzódásának elősegítésében játszik szerepet. Az $\alpha$-simaizom-aktint tartalmazó myofibroblastok nagy mennyiségú kollagént, hialuronsavat és byglican PG-t, és csak kis mennyiségü keratán-szulfát-tartalmú PG-ket szintetizálnak. Ennek következménye egy dezorganizált, opálos ECM kialakulása [4]. A myofibroblast-szaporulat létrejöttében a cornealis epithelium és a bazális membrán kulcsszerepet tölt be [23], ez bizonyítja a bazális membrán kiemelkedő szerepét a cornealis sebgyógyulásban [24].

A sebgyógyulás folyamán myofibroblastok átalakulhatnak fibroblastokká, amelyek csakúgy, mint a keratocyták, nagy mennyiségú kollagént, keratocant, lumicant szintetizálnak, ezáltal organizált, transzparens ECM-et formálnak.

A stromalis reparáció során a keratocytákat stimuláló növekedési faktorok öt különböző helyről származhatnak (2. táblázat). A cornea stromájában, a könnyfilmben, a macrophagokban és gyulladásos sejtekben, az epitheliumban, valamint a keratocytákban egyaránt termelődnek növekedési faktorok [4]. A már említett IL-1 - amely a cornealis epitheliumban, a keratocytákban és a fibroblastokban termelődik - fontos regulációs szerepet

2. táblázat | Növekedési faktorok és termelődési helyük a cornealis sebgyógyulás során

\begin{tabular}{ll}
\hline Könnyfilm & TGF- $\alpha$ \\
\hline Epithelium & IL-1, TGF- $\beta$ \\
\hline Stroma & IGF-I, IGF-II \\
\hline Macrophagok és gyulladásos sejtek & EGF \\
\hline Keratocyták & IL-1, FGF-2, CTGF, KGF \\
\hline
\end{tabular}

CTGF $=($ connective tissue growth factor $)$ kötőszöveti növekedési faktor; EGF = (epidermal growth factor) epidermalis növekedési faktor; FGF-2 = (fibroblast growth factor) fibroblastnövekedési faktor; IGF-I = (insulin-like growth factor I) inzulinszerü növekedési faktor I; IGF-II = (insulin-like growth factor II) inzulinszerú növekedési faktor II; IL-I = interleukin- 1 ; KGF $=($ keratinocyte growth factor) keratinocyta növekedési faktor; TGF- $\alpha=($ transforming growth factor $\alpha)$ transzformáló növekedési faktor $\alpha$; TGF- $\beta=$ (transforming growth factor $\beta$ ) transzformáló növekedési faktor $\beta$. játszik a keratocyták apoptózisában, illetve az életképes sejtek aktivációjában, ezáltal a stroma szöveti organizációjában. Az IL-1 ezenkívül serkenti a keratocytákban a KGF (keratinocyte growth factor) termelődését [22]. A stromában termelődő IGF-I és IGF-II sebgyógyulás alatt aktiválják a keratocytákat, amelyek ezen növekedési faktor hatására proliferálni kezdenek és ECM-et termelnek. IGF-I-receptorok az epithelialis sejteken is megtalálhatóak [25], így az IGF-I a könnyfilmben termelődő TGF- $\alpha$-val együtt az epithelialis sejtek migrációját serkenti [26]. A macrophagok által termelt EGF szintén a cornealis epithelen fejti ki hatását. Maga az epithelium is képes növekedési faktorok szintézisére. Az itt termelődő TGF- $\beta$ hatást gyakorol a stromalis keratocytákra, ezáltal önmaguk is képesek lesznek növekedési faktorok szintézisére. A KGF (keratinocyte growth factor), a TGF- $\beta$ hoz hasonlóan, a keratocytákat növekedési faktor termelésére serkentik, ezáltal a keratocyták önmaguk és más keratocyták proliferációját és ECM-termelését fokozzák, azáltal, hogy FGF-2 és CTGF (connective tissue growth factor) növekedési faktorokat termelnek [26].

Az FGF-2 a sejtproliferációt nagyobb mértékben stimulálja, mint a kollagénszintézist, nem úgy, mint az IGF-I és a TGF- $\beta$. Ezek a növekedési faktorok nagyobb mértékben stimulálják a kollagénszintézist és kevésbé a sejtproliferációt. A TGF- $\beta$ ezenfelül stimulálja a hialuronsav, fibronectin, valamint a byglican szintézisét is, így szerepe lehet a fibrotikus ECM kialakításában is, valamint sebgyógyulás során a myofibroblast-transzformációt regulálják [4].

\section{Következtetések}

Az öt rétegből felépülő cornea nagy része kollagénrostokból és proteoglikánokból felépülő extracelluláris mátrixból áll. Ezen komponensek rendezett elhelyezkedése teszi átlátszóvá a szaruhártyát [1]. A cornea fóleg I-es és V-ös típusú kollagénrostokból áll. Az I-es típusú kollagén a fó fibrillumformáló kollagén, míg az V-ös típusú kollagén a proteoglikánokkal együtt a kollagénrostok egyenlő átmérőjének kialakításában játszik fontos szerepet. Az ECM négy fó proteoglikánja a mimecan, lumican, keratocan és a decorin [8].

A kollagénrostok és a proteoglikánok a cornea embrionális fejlődése, valamint a sebgyógyulás alatt is fontos szerepet töltenek be az egyedi ECM-elrendeződés kialakításában, valamint megőrzésében. Sérülés esetén a stromalis reparáció során a növekedési faktorok is fontos szerepet kapnak, mivel ezek regulálják az ECM szerveződését [26]. A növekedési faktorok (IL-1, TGF- $\alpha$, TGF- $\beta$, FGF-2, IGF-II, EGFR, CTGF) termelődhetnek a könnyfilmben, az epitheliumban, a stromában, a keratocytákban és a macrophagokban is. A növekedési faktorok a keratocyták stimulálása révén extracelluláris mátrix termelést indukál, és arányuktól függően rendezett ECM vagy hegszövet alakul ki [4]. 
Anyagi támogatás: NAP_KTIA_13_NAP-A-II/7 (HT); AGR_PIAC_13-1-2013-0008.

Szerzôi munkamegosztás: A kézirat elkészítésében mind a négy szerző részt vett. A szerzők a kézirat végleges változatát elolvasták és jóváhagyták.

Érdekeltségek: A szerzőknek nincsenek érdekeltségeik.

\section{Irodalom}

[1] Michelacci, .. M.: Collagens and proteoglycans of the corneal extracellular matrix. Braz. J. Med. Biol. Res., 2003, 36(8), 1037-1046.

[2] Szalai, E., Felszeghy, Sz., Hegyi, Z., et al.: Fibrillin-2, tenascin-C, matrilin-2, and matrilin-4 are strongly expressed in the epithelium of human granular and lattice type I corneal dystrophies. Mol. Vis., 2012, 18, 1927-1936.

[3] Meek, K. M., Fullwood, N. J.: Corneal and scleral collagens - a microscopist's perspective. Micron, 2001, 32(3), 261-272.

[4] Hassell, J. R., Birk, D. E.: The molecular basis of corneal transparency. Exp. Eye Res., 2010, 91(3), 326-335.

[5] Hayashida, Y., Akama, T. O., Beecher N., et al.: Matrix morphogenesis in cornea is mediated by the modification of keratan sulfate by GlcNAc 6-O-sulfotransferase. Proc. Natl. Acad. Sci. U.S. A., 2006, 103(36), 13333-13338.

[6] Von der Mark, H., von der Mark, K., Gay, S.: Study of differential collagen synthesis during development of the chick embryo by immunofluorescence: I. Preparation of collagen type I and type II specific antibodies and their application to early stages of the chick embryo. Dev. Biol., 1976, 48(2), 237-249.

[7] Robert, L., Legeais, J. M., Robert, A. M., et al.: Corneal collagens. Pathol. Biol., 2001, 49(4), 353-363.

[8] Scott, J. E.: Extracellular matrix, supramolecular organisation and shape. J. Anat., 1995, 187(Pt 2), 259-269.

[9] Prydz, K., Dalen, K. T.: Synthesis and sorting of proteoglycans. J. Cell Sci., 2000, 113(2), 193-205.

[10] Chen, S., Mienaltowski, M. J., Birk, D. E.: Regulation of corneal stroma extracellular matrix assembly. Exp. Eye Res., 2015, 133, 69-80.

[11] Lewis, P. N., Pinali, C., Young, R. D., et al.: Structural interactions between collagen and proteoglycans are elucidated by three-dimensional electron tomography of bovine cornea. Structure, 2010, 18(2), 239-245.

[12] Sun, M., Chen, S., Adams, S. M., et al.: Collagen V is a dominant regulator of collagen fibrillogenesis: dysfunctional regulation of structure and function in a corneal-stroma-specific Col5al-null mouse model. J. Cell Sci., 2011, 124(23), 4096-4105.

[13] Meek, K. M., Leonard, D. W.: Ultrastructure of the corneal stroma: a comparative study. Biophys. J., 1993, 64(1), 273-280.
[14] Müller, L. J., Pels, E., Schurmans, L. R., et al.: A new three-dimensional model of the organization of proteoglycans and collagen fibrils in the human corneal stroma. Exp. Eye Res., 2004, 78(3), 493-501.

[15] Kao, W. W., Liu, C. Ү.: Roles of lumican and keratocan on corneal transparency. Glycoconj. J., 2002, 19(4-5), 275-285.

[16] Boubenni, R., Hart, M., Al-Jastaneiah, S., et al.: Immunohistochemical expression and distribution of proteoglycans and collagens in sclerocornea. Int. Ophthalmol., 2013, 33(6), 691-700.

[17] Amjadi, S., Mai, K., McCluskey P., et al.: The role of lumican in ocular disease. ISRN Ophthalmol., 2013, 2013, 632302.

[18] Chakravarti, S., Petroll, W. M., Hassell J. R., et al.: Corneal opacity in lumican-null mice: defects in collagen fibril structure and packing in the posterior stroma. Invest. Ophthalmol. Vis. Sci., 2000, 4l(11), 3365-3373.

[19] Nakazawa, K., Hassell, J. R., Hascall, V. C., et al.: Defective processing of keratan sulfate in macular corneal dystrophy. J. Biol. Chem., 1984, 259(22), 13751-13757.

[20] Pellegata, N. S., Dieguez-Lucena, J. L., Joensun, T., et al.: Mutations in KERA, encoding keratocan, cause cornea plana. Nat. Genet., 2000, 25(1), 91-95.

[21] Meier, S., Hay, E. D.: Stimulation of extracellular matrix synthesis in the developing cornea by glycosaminoglycans. Proc. Natl. Acad. Sci. U.S.A., 1974, 71(6), 2310-2313.

[22] Wilson, S. E., Mohan, R. R., Mohan, R. R., et al.: The corneal wound healing response: cytokine-mediated interaction of the epithelium, stroma, and inflammatory cells. Prog. Retin. Eye Res., 2001, 20(5), 625-637.

[23] Wilson, S. E.: Corneal myofibroblast biology and pathobiology: generation, persistence, and transparency. Exp. Eye Res., 2012, 99, 78-88.

[24] Torricelli, A. A., Wilson, S. E.: Cellular and extracellular matrix modulation of corneal stromal opacity. Exp. Eye Res., 2014, 129, 151-160.

[25] Li, D. Q., Tseng, S. C.: Three patterns of cytokine expression potentially involved in epithelial-fibroblast interactions of human ocular surface. J. Cell. Physiol., 1995, 163(1), 61-79.

[26] Yu, F. S., Yin, J., Xu, K., et al.: Growth factors and corneal epithelial wound healing. Brain Res. Bull., 2010, 81(2-3), 229235. 